Article

\title{
The Sustainable Imperative-Smart Cities, Technology and Development
}

\author{
Gusti Ayu Made Suartika ${ }^{1, *(1)}$ and Alexander Cuthbert ${ }^{2}$ \\ 1 Master Program in Planning \& Development, Denpasar Campus, Udayana University, \\ Denpasar 80232, Bali, Indonesia \\ 2 Faculty of the Built Environment, Kensington Campus, University of New South Wales, Kingsford, \\ Sydney 2022, NSW, Australia; a.cuthbert@unsw.edu.au \\ * Correspondence: ayusuartika@unud.ac.id; Tel.: +62-896-8550-1932
}

Received: 12 September 2020; Accepted: 24 October 2020; Published: 27 October 2020

\begin{abstract}
This paper investigates the relationship between the smart city concept and its applications that are heavily technologically focused. Using principles derived from political economy, it denies the "smart city" approach as an idealist/utopian solution to urban problems and focuses on what the smart city is. We also maintain that the smart city cannot be considered an independent force in urbanization. While the benefits of technology are undeniable, such technologies are frequently applied prior to establishing appropriate social and legal controls. We therefore focus on the sociopolitical dimensions of the debate and do this by compounding the smart city ideology with two other social constructs, namely the concept of "sustainable development" on the one hand and "natural capitalism" on the other. In combination, these three ideologies are mutually dependent. They promote a concentration of private capital and are perpetuated as ideological structures focused on capital accumulation rather than equality and social democracy. Following these trends, much research on smart cities appears to be compromised, and a new ethical approach is required. In conclusion, we suggest that the smart city concept and its implementation must realign itself to this objective if democratic principles founded upon social justice are to be promoted.
\end{abstract}

Keywords: natural capitalism; sustainability; smart cities; technology; history-theory

\section{Introduction}

"The Architects of the smart cities have utterly failed to reckon with the reality of power, and the perennial ability of various elites to suppress policy directions they find uncongenial to- - that word again—their interests" [1] (p. 59).

"If all possible scientific questions be answered, the problems of life have still not been touched at all" [2] Kindle location. 2883).

This article is contextualized by a condition in which the use of technology is seen to be uncritically accepted by many writers. In this context, this paper fully accepts that in a vast number of cases, the benefits of technology in the realms of medicine, science, education, industries, communication, economy, and other social forms have been outstanding. However, there are very few articles that actually discuss the limitations of technology from the perspective of social science and political economy. This situation reflects a century long debate between natural science and social science. This is not a debate that the authors seek to resolve in this paper. We aim to balance out the social over the technical, and we apologize in advance for the fact that by its very nature, political economy adopts a critical approach to urban problems and that the debate within the discipline is as great as it is with other philosophies and theories. This should be interpreted as animus, merely as a search for the truth. 
So, while the advantages of technology over historical time are transparent, our purpose has been to reign in an uncritical approach to new technologies in whatever field they occur. So, we accept the fact that our position is one of a critique of the smart cities and its attendant technologies. In short, our position does not attempt to present a balance perspective, since it appears to us that the general support is in favor of an uncritical adoption of technologies, particularly in reference to smart cities. In adopting a critical perspective, we wish to stress the significance of the economic and political dimensions over the technical and in so doing, move the debate over the smart city back to center. For all of the above reasons, the influence of political economy on the smart city offers a substantially new approach, currently lacking in the existing literature.

Given these objectives, we wish to stress that we are not Luddites. In presenting our argument, we wish to express that we are in no sense blind to the vast improvements to human lives that technology has offered. It is quite clear that the development of global civilization has massively depended on technological innovation and progress. We would also like to add that we fully appreciate and have learned from the multitude of papers that have offered a scientific focus. Despite these clear advantages, we feel that the untrammeled use of technology without a social critique of its consequences is undesirable and undemocratic.

The smart city concept is a perfect reflection of the economic and political interests of capital at the dawn of the 21st century-a period already initiated as the fourth industrial revolution $[3,4]$. The first three industrial revolutions were based in the productive capacity of technological control over natural elements and information - steam in the first (mechanization of production), electricity in the second (massification) and industrial technology (automation) in the third. The difference today is that artificial intelligence is now driving development. Due to accelerating growth it seems inevitable that the state will remain one step behind in its attempts to implement legitimizing social sanctions. Private sector influence and a new form of technological and political imperialism places the smart city outside the reach of most national, state and local governments. This does not bode well for the survival of democratic principles in structuring urban development. The last fifty years has been marked by the increasing influence of private sector interests over the formation and administration of state policy [5]. Until 1960, the major function of the state was to provide items of collective consumption to the general population (housing, schools, health services, etc. [6]. The role of the private sector was to look after business [7]. Between roughly 1960 and 1990, a new era arose where various fiscal crises effectively allowed the private sector to influence state policy due to its superior capacity in funding necessary infrastructure and government projects through public-private sector partnerships. Post 1990, state neocorporatism rapidly evolved from merely influencing state policy into a situation whereby private capital not only provided loans and advice to government, it now takes part in writing the rules it wishes to live by with the potential legitimating crisis this implies [5].

However, in this context, the smart city presents as politically inert and functional-a panacea for a multitude of social problems (except wealth redistribution) - and only providing benefits by improving efficiencies through technology for all citizens. But such claims are false. Henri Lefebvre once said "all space is political", and we suggest the same is true for technology and the smart city [8]. We maintain that such technologies are not neutral agents in creating use values. Capitalism is a class divided political system. So inevitably, the use of technology is politicized to advance the commodification of society and deepen the grip of capitalism on human agency. In this context, how is the smart city to be understood-as a politically neutral and necessary technology that reflects the 21st century needs and aspirations; as the natural outcome of urban development; or as an inherently politicized strategy of state neocorporatism? While each position has its supporters, our position is that the smart city is ideologically compromised by business interests. It represents a massive opportunity for profit by creating a new market for commodities, a fundamental principle of capital accumulation over the last 300 years. However, as in the adoption of sustainable development discussed below, corporate interests present with one face but the actuality is rather different. 


\section{Materials and Methods}

In contrast to many scientific articles which usually implement the rational scientific method, substantially based on quantification, testing, the design of technical processes and the use of materials, this paper is somewhat different. In contrast, it adopts a historically defined theoretical framework called political economy that has evolved over 250 years of historical development since Adam Smith (1776). Similarly, any adopted method emerges from the theory and cannot be abstracted away from its fundamental principles. It is unavoidably both qualitative and critical. Hence there is no standard method in political economy that exists in and of itself. Political economy at its most fundamental constitutes a radical critique of capitalism, its history, ideologies, practices and effects [9].

Political economy does not however constitute a singular totalizing theory. It is rather a federation of concepts that focus on social change such as modes of production, social class, legitimation, commodification and issues such as gender, exploitation, resource depletion, global warming and the use (and abuse) of technologies [10-13]. Consequently, our method emerges from the relationship between theoretical principles and technological development. Below we discuss the organic composition of capital and its technical composition in the context of smart city ideology where technology is sanctified as the dominant trajectory of urban development. In order to expose some of the problems associated with smart city ideology and its promotion of a digital lifestyle through technology, we link it to the political economy of sustainable development and that of natural capitalism. In so doing the technical offerings of the smart city can be integrated with the political dimensions of state neocorporatism and the illusion of a new beneficent age of capital. This permits us a full critique of the concept "smart city" which presents as a neutral a-political technical process and the benevolent application of technology to human purposes. As we will see, this singular application of technology to urban life rapidly unravels when the social and political dimensions come to the fore, with the demand that a new moral economy must align with the technical.

In following the above principles, we now outline our analytical process that leads to our conclusions. We also reiterate that political economy is not a rational scientific process based in mathematical equations and algorithms. So, in following a social science perspective, there is no "proof" to our argument. The measure of its worth is in the clarity of the logic that we offer. Rationality is not confined to natural science, and qualitative reasoning contains its own integrity and logic. Our research method and design adopt the following processes.

First, it begins by interrogating numerous definitions of the smart city concept given the literature on the subject and the numerous relevant research studies that have been carried out to date. The second phase moves from attempts to contain and encapsulate the smart city idea to its place as a new technology that possesses many questionable suppositions. Because these ideas cannot be adequately explained from within the smart city model, we place their progress within the history of technological advancement as a whole, as we do later with historical urban development. Third, we address what we see as the Achilles heel of smart city development. In principle we suggest that the smart city concept cannot be understood solely from within its own definitions of itself. Any such trajectory must fail since there can be no substantial theory or critical self-reflection possible. This is politically dangerous since it presents as a method without a theory. We can only surface the problems of such a position by situating the smart city within concepts of urban development as a whole, that is as the object of substantial theory existing for centuries. Fourth, the same basic cultural world view also locates the smart city not as a neutral or anodyne process but as a function of the history of urban development. We contrast the idea of "smart" as a biased politically neutral descriptor, where countless examples of real creativity are set to one side, and to a degree submerged in favor of highly commodified technologies. Fifth, we then link the smart city to the idea of natural capitalism, in the context that the inequalities of capitalism will somehow right themselves and that the smart city is a logical part of this process. Finally, we relate this context to prevailing ideas on sustainable development. Each of these stages will now be amplified below. 


\section{Results and Discussions}

\subsection{Smart Cities-Definitions, Research and Analysis}

As in any new phenomenon, much smart city literature is naturally concerned with what the object of study actually is. Paradoxically there is no such thing as a city that can be isolated from the totality of urban development and urban politics [14]. At its best "the city" is a high density bureaucratic and political entity adrift in a sea of varied urbanization. The smart city is then an anomaly since it contradicts the overall nature of urban development-there is no satisfactory working definition of "a city." Much research reflects this confusion. The literature on Smart Cities is now profuse and seemingly endless in its need to categorize, quantify, define, compare and model the concept. However, years ago, the idea of modelling cities was demolished by Andrew Sayer who noted that anything not quantifiable was usually left out, that is all human needs, desires and opportunities, those life enhancing prospects that are important to everybody [15]. Definitions and methodologies abound with no resolution to the perceived inadequacy of existing "data". A single academic paper out of hundreds has itself assembled 25 definitions of smart cities, with six different assemblies of "key elements" each of which contain some eight dimensions [16]. Cross referencing these functions alone would have infinite variation. One might think this was sufficient in itself. Others have suggested eight ecosystem "layers" and another paper contains 126 references all from Google Scholar focusing on smart cities and their referents. So, the repetition of "metrics" is already endless, having terminated with the idea that "everyone is right" [17]. On the other hand, this is countered by the idea that "digital stardust won't magically make future cities more affordable or resilient [18]." All of this generates a serious dilemma as to what exactly is going on, and why more metrics might be necessary.

If the above is indeed true, the situation clearly demands that the entire logic of the smart city needs rethinking. Once treated purely as a technology [19], it becomes detached from the social reality of urban politics and urban life [20-23]. Because of this, the same information can be continually recycled and redefined in a myriad of different ways, all set to pursue the truth and to multiply beyond reason in future research with little possibility of any real resolution. It is this confusion that plays entirely into the hands of big capital. In the meantime, certain apparently obvious insights are bypassed and capital gets on with business, unaffected by academic research [24]. The problem for the smart city is that there is no omega point since its sole stated purpose is efficiency (of climate, transport, government, domestic life, etc.). We maintain that the smart city cannot be defined in its own terms and must be seen as an integral part of the political economy of states, nations and global development. If correct, this perspective demands that the smart city should be recognized as a different phenomenon wherever it happens to occur (Mexico, Mauritius, Silicon Valley, etc.). It cannot be defined in the abstract. Consequently, there can be no definition that is useful given the prevailing requisite variety of political systems, cultures and ideologies. We recollect Alfred North Whitehead's dictum that "it is more important that a proposition be interesting than it be true" — such as reversing the title of the paper "Smart Cities, Sustainable Cities or Both" to "Smart Cities, Sustainable Cities or Neither?" The answer to the first is both axiomatic and low in refutability - of course we want to be smart and sustainable. In the second we actually have to think in some depth as to what is being inferred. Overall, the retreat into the comfort of a purely technological definition is appealing if we continue to think of technology as a depoliticized functional process. However, we then have to ask "what is technology and what is its social function?"

\subsection{Technology and Its Roles in Smart Cities' Development}

Technology is the process by which raw materials (nature) are transformed by human labor to produce use values. According to Marx "the history of manufacture-both processes and products, is the history of class relations" [25]. This idea is also manifest in the smart city ideology, where a new knowledge class has become the defining factor in "smartness" [26,27]. This idea is not new and has a long history, starting with Mikhail Bakunin in the 1870s who saw the emergent bureaucracy 
within Russia as a "new class" [28], continuing through Milovan Djilas in 1957 and Alvin Gouldner in 1979 [29,30]. However, over a century and a half, the nature of this new class has shifted from bureaucrats to intellectuals and today to technocrats—Richard Florida's "creative class" [31].

In neoclassical economics, much store is invested in the idea that technology is a major contributor to economic growth. Exactly how true this proposition is recently exposed in Walter Piketty's massive text Capital [31]. He contradicts the idea that technological growth can of itself change very much in terms of real wealth [32]. "The key point is that there was no historical example of a country at the world technological frontier whose growth in per capita output exceeded $1.5 \%$ over a lengthy period of time" [18] (p. 96). Usually it is significantly lower. So, Piketty destroys the myth that a more democratic politic is currently trending-pressure by capital to increase output is inherent. The graphs clearly demonstrate that nation states seem permanently doomed to virtual bankruptcy, where total income to the state in wealthy countries is more or less equal to national debt. In contrast, private capital is worth up to $700 \%$ of national income, e.g., Japan (Table 1). "Regardless of the imperfections of measurement, the crucial fact here is that private wealth in 2010 accounts for virtually all of national wealth-more than 99\% in Britain and more than 95\% in France according to latest estimates" [31] (p. 125).

Table 1. Proportion of Public and Private Capital of National Capital.

\begin{tabular}{ccccc}
\hline \multirow{2}{*}{ Country } & \multicolumn{4}{c}{ Value of Capital (\%) } \\
\cline { 2 - 5 } & \multicolumn{2}{c}{ Public Capital } & \multicolumn{2}{c}{ Private Capital } \\
\cline { 2 - 5 } & \multicolumn{2}{c}{ Year } & $\mathbf{1 9 7 0}$ & $\mathbf{2 0 1 0}$ \\
\cline { 2 - 5 } & $\mathbf{1 9 7 0}$ & $\mathbf{2 0 1 0}$ & 300 & 400 \\
\hline United States & 60 & 40 & 220 & 400 \\
\hline Germany & 80 & 40 & 300 & 500 \\
\hline Britain & 80 & 5 & 240 & 300 \\
\hline Canada & 80 & 40 & 300 & 600 \\
\hline Japan & 60 & 40 & 300 & 580 \\
\hline France & 60 & 40 & 240 & 680 \\
\hline Italy & 15 & -80 & 340 & 520 \\
\hline Australia & 60 & 70 & \\
\hline
\end{tabular}

Clearly the use of technology is predominantly in the interests of the private sector and the purpose of civil society is to keep the production and consumption of commodities flowing smoothly. So, it appears that technology is not the panacea for development that it is claimed to be. It also seems that socially generated wealth is increasingly concentrated in private hands [32]. The wealth of corporations and the number of billionaires increases annually. The American company Walmart is the tenth largest economic entity in the world beating that of countries such as Australia, South Korea and India. Concomitantly, in the last six years the number of billionaires has doubled from 1226 in 2012 to 2754 in 2018, whose collective worth in 2018 was \$US 9.2 trillion [33]. Walmart is the tenth largest economic entity in the world, the top of the top ten companies, where half of the remainder are oil corporations. Singh calls the smart city "a $\$ 1.5$ trillion market opportunity" without saying who gets the opportunity [34]. On this basis we can safely assume that the smart city is a smart method of promoting this gulf in wealth and power between capital and the mass of ordinary people.

In this somewhat totalizing process, technology has three major social functions that affect the growth of Gross Development Product (GDP). First, it changes the organic composition of capital (OCC) - the ratio of constant capital (capital invested in plant, equipment and materials) to variable capital (capital invested in the labor costs involved in hiring employees). Second, in the technical composition of capital, the rising organic composition of capital is a necessary effect. The higher the 
composition, the more technology is used to replace human labor with the potential consequence that surplus value increases along with profits-i.e., robots are on the rise [34]. The endgame implies that the organic composition is increased to the point where no human labor is involved. Technologies inexorably replace labor or subordinate it as servomechanisms of production. Third, the consequences are several, such as new forms of economic imperialism, increased demands for a minimalist state, socially necessary unemployment, the alienation of labor from their own creativity, increased technological domination of populations through surveillance and the potential for civil unrest due to the unequal distribution of the surplus product (the wealth that individuals create but do not share). Finally, a new class system is demanded by the division of society into knowledge classes on the basis of their command over technology, making George Orwell's Brave New World alpha to delta class structure that much more likely $[35,36]$. How this changeover will happen is anybody's guess. However, in order to further our understanding of this situation, the use of theory needs to be investigated.

\subsection{Theory—The Achilles Heel of Smart City Analysis}

In addition to the above problematic in defining the term "city", the use of the word "smart" is anthropomorphic and displaces analysis of actual problems to those that are superficial. The smart city is a deliberate misnomer, whereby it can be given credit for its own development. However, only people can be smart, and the so called "smart city" is a deviant term that only exists as a reality in the portfolios of businesses that want to boost their market share. More importantly, anthropomorphism, (the process of according inanimate objects with human qualities)—facilitates the absence of any substantial theory through the separation of politics from technology and by presenting itself as a sterilized and depoliticized social event. It presents as technological progress in a wholly benign form, where all outcomes are seemingly beneficial. So, the smart city is insufficiently smart to generate any critical self-reflection or substantial theory since this is potentially anathema to the ideology of smart city development. The concept then becomes an a-social, depoliticized ephemerality, a tool open to all forms of exploitation and abuse by big capital [37]. While the terms "smart" and "city" are interlinked, "smart" is assumed. Clearly there is no conspiracy to promote a sanitized urban politic, nonetheless the smart city seeks to be judged as a piece of technology rather than the promotion of social engineering. None of this seeks to deny that certain economic efficiencies might be welcome and that civilization has depended for its existence on the incredible changes that technology incurs. So, the amazing benefits we now enjoy are not in question. The question is whether or not democratic society makes the decisions about urban development or whether a new society emerges on the back of new technological advancement largely controlled by corporate wealth and political influence.

In contrast to the smart city cultural world view, the concept "city" is the reality that has entertained scholars for millennia, with the concept "Urban" debated intensively for over a decade as the foundation for Urban Sociology $[14,38]$. However, in most cases the vast literature on urban development that allows us to understand how urbanization takes place is largely bypassed in the smart city literature, where somehow time has frozen solid and we can now work out how to implement smart cities on the basis of new technologies alone [39-42]. So, analysis of the concept gets stuck at a superficial level. If we have smart cities, we can also have dumb cities, not so dumb cities, healthy cities, sick cities, psychotic cities and the entire plethora of descriptors besetting the human condition. While it can be argued that the term "smart" is harmless, and is only used to convey certain ideas about technological efficiency, the actual benefits and uses of technology are seldom discussed. It is safer to accept the fact that both "smart" and "city" taken together are content free and cannot in any way be deployed meaningfully in urban analysis. The absence of powerful theory consequent upon this overall situation plays exclusively into the hands of state neocorporatism. Since the object "smart city" is undefinable and seemingly politically neutral, it is open to all forms of intervention. In the process, the state is reduced to a vehicle whose central purpose is to facilitate private enterprise rather than the social good, with the benefits of the former seemingly trickling down to the general populace. The traditional 
function of urban planning - that of regulation — can then be obviated by public-private partnerships, allowing capital to increasingly write up the rules it wishes to live by and subverting democratic control over urban life [43-46].

Over historical time, cities have grown and decayed in equal measure. The political economy of urbanization has in principle creative destruction as its guiding philosophy $[47,48]$. The reasons for this are apparent-wars, invasions, migration, catastrophes, disease, but to the fore, capital accumulation from land development. This is facilitated by the continual destruction of "fixed" capital constituted in the built environment as "Capital represents itself in the form of a physical landscape created in its own image" [5] (p. 113). The smart city is merely a variation on this theme. Since the "image" is of course founded on class conflict, competition and the destruction of nature, this maxim will likely proceed over the remainder of this century [49-51]. While the smart city appears simply as superior technology, pre-existing urbanization suggests that the historical heritage of place demands supremacy and is embedded in populations and environment alike. The refusal of Santa Maria Tonantzintla in Mexico represents a microcosm of potential resistance to smart city ideology, based upon its historical urban fabric-it rejected outright the entire smart city portfolio [52]. However, in the state of Puebla alone, 15 cities are already slated to join the smart city bandwagon. In addition, a new form of imperialism is being introduced. China as a major provider of digital technologies is prepared to fund smart city developments such as those in Mauritius where projects already have Chinese names—such as Jin Fei and Yihai and may also be interpreted not as pure philanthropy but as part of a China's burgeoning imperialism in the Global South [53,54].

\subsection{History and the Smart City}

Overall, the smart city concept is presented as a phenomenon that has no historical referents, one where history has no role to play. However, there is clearly an analogy with, e.g., prior post war new town systems in America, Britain, France, Sweden and the rest of Europe but without similar justification [55]. Much of the existing literature on smart cities treats it as "an abstract analytical concept rather than a socio-historical phenomenon" [56] (p. 1098). However, the lessons of history also challenge the whole idea of smartness as a seemingly contemporary quality. Take the example of Florence during the 15th and 16th century when it was at the center of the Italian Renaissance. This was where merchant capitalism originated, and the generated wealth inspired an explosion of creativity that had not been seen since the Ancient Greeks. The architecture lives on today and pays homage in, e.g., the Uffizzi Gallery. It is best known as a show piece for the priceless paintings of the period. However, it was first built as an Uffizzi-the original typology of today's "office" marking a tectonic shift from barter to paper based legal agreements and contracts. The sheer inventiveness of the Florentines was staggering. The Cathedral of Santa Maria del Fiore begun in 1296 took 140 years to build. By 1418 after 120 years, the cathedral had been completed up to the base of the dome, where it halted since nobody knew how to build it [57]. The technology of the time was not up to the task, and the job was awarded to Brunelleschi on the basis of a competition. He had to work out how to raise 37,000 tons of masonry over 50 metres into the air to execute the construction without internal scaffolding. The technology invented to complete the cathedral was sheer genius. Leonardo Da Vinci also soldered a three-metre bronze ball together to be placed on top of the spire that had to be raised 350 feet and was itself a consummate act of engineering.

There are many observations that can be made here about the origins of smartness and creativity - the instigation of the capitalist enterprise in the nascent form of mercantilism, the educational system based in patronage that encouraged extraordinary creativity, the flourishing of art in all of its forms, the inventiveness of the population, etc. However, there is an underlying implication that all prior cities were somehow lacking in smartness. Otherwise why use the word smart now? However, the key point rests on the principle that the proposed "smart cities" are feeble propositions when compared to countless historical examples of creative urban genius. Sir Peter Hall goes into great detail of 21 "creative cities", with an editorial stating that "every golden age has been an urban age; 
throughout history, cities have provided a crucible for creativity" [58] (p. 7). If we examine the history of urban development, we are met with an astounding array of "smartness" and it is arguable that every major city has its fair share of smartness in its evolution. Given that the range of development contexts covers the entire planet, the idea that one solution fits all in the form of the smart city has to be seriously compromised. The only dimension that is useful in any future development perspective is the manner in which any urban area has evolved into its present condition. An analysis of the chosen environment-village, town, city, conurbation, urbanized region, new town etc. and how it has succeeded or failed is vital to any forward movement [59]. There is however another position that argues for more modest versions of cities based upon medium density housing and relegating the idea of smartness to the woodpile [60]. The overall implication is that lifestyle not profit should be the aim, a goal alien to the smart city with yet more soulless towers and sterile environments. Leicester in England is exemplary and can be praised for its "remarkable absence of spectacle" where "visual richness and authenticity" are rife [61]. This should be the priority not only in the smart city but also in urban development generally over efficiency and profit. In order to deepen understanding of smart city ideology, we now turn to the two dominant and interlinked political strategies that together reinforce smart city development.

\subsection{The Smart City, Natural Capitalism and Hidden Agendas}

The proposition that "natural capitalism" is remotely applicable to the foundation for the capitalist world system must be rejected. The concept was initially promoted by Hawken et al. In 1999 [62] and has since been adopted by many other scholars [63]. As in the imaginary world of smart cities, the idea appears not only benign but also benevolent and philanthropic in its presentation. Nonetheless it is subject to similar flaws-the main one being that there is nothing whatever natural about capitalism, despite the idea that it offers a "New Utopia" and is unlikely to resolve Wittgenstein's dilemma stated above-how to live [64]. So, the core idea expressed in "Natural Capitalism" is that the global capitalist system will somehow morph into an acceptable state without any change in its fundamental structure (social class, private appropriation of the surplus product, private ownership of the means of production, minimalist state intervention, a necessary reserve army of unemployed, etc.). This constitutes the alpha point of the moral question-whether it is correct for private enterprise to condense capital and power into its own immoral compass when this is exclusively accomplished by the exploitation of nature and man, where both survive as property relations. The concept is presented as a solution to urban problems while uncritically maintaining all the structural and oppressive features of the capitalist world system "To make their central claims, natural capitalists celebrate certain principles of capitalist ideology, yet condemn contemporary and past capitalist practice" [65] (p. 70). Natural capitalism has been severely criticized as ideologically unsound if not downright devious [66-68], and only a fraction of this overall debate can be presented here.

Natural capitalism adopts the stance that there is nothing fundamentally flawed about the existing system and that whatever flaws do exist will have technical fixes-as in smart city solutions for perceived urban problems. This assumption does not factor in that market economics have no moral compass, as promoted in Milton Friedman's dictum "Greed is Good." The amoral imperative that the ownership of the entire planet remains, and should continue to remain in private hands-"a monistic distortion (by which everything is considered capital)—is introduced and the reciprocal independence among factors of production as sources of value is eliminated" [69] (online). The combination of the market mechanism and Darwinian ideas seem to guarantee the gradual transition of capitalism into a more benign, efficient and democratic body politic [63]. The expansion of even more efficient technologies is best seen to be delivered by market equilibrium, making, e.g., profit out of waste, thus denying the need to exploit nature in the manner that all economies have done since the origins of capitalism in the 16th Century. The argument is that there is no threat on the horizon that technology cannot overcome. 
Within this system, nature is viewed as a provider of goods and "services" which can then be incorporated into a totally commodified planet where everything has its price, akin to a gigantic and benevolent supermarket where nature endlessly supplies goods free of charge. In the Grundrisse Marx refers to this process as "the primeval forest rate of interest" - the expropriation of ancient natural heritage at no cost. Take the following comments for example: "Benefits of valuing nature ... work out ways to create markets for ecosystem services ... ... ecosystem services worth at least $\$ 36$ trillion annually" [70] (online). Alternatively stated, capital receives a vast subsidy from nature of this amount for free and without which it could not function. A market value then needs to be placed on all natural processes and products. Nature is now referred to as "green infrastructure", biodiversity as "asset classes", and habitats as "ecosystem markets." The totality of all human and natural processes is then reduced to the commodity principle, the holy grail of market capitalism, with the effect that "the natural world is being effectively pushed even further into the system that is eating it alive" [71].

The idea of nature having any intrinsic merit is anathema to this system, which claims to have no political bias. The implementation of a triple bottom line approach to urban projects where all the costs (social, environmental and economic) are accounted for remains a utopian future. Monbiot goes on to describe how at the highest level, the British Government's Ecosystems Markets Task Force is in collusion with the City of London, in "a final bid to totally commodify the natural world through the use of revenue streams and securitisations to enhance the return on an 'environmental bond.'" The same task force suggests that "we need to unbundle ecosystem services so they can be individually traded" [70] (online). Belief in the market mechanism is so absolute that state controls and social planning are viewed as unnecessary appendages to the free will of market capitalism- "See, if you look at the drug war from a purely economic point of view, the role of the government is to protect the drug cartel. That's literally true" [72] (online). In this world view, sustainability is perceived as a guaranteed outcome of technological progress rather than political innovation or a reduction in the quantum of Gross Development Product (GDP). Nature is assumed to be owned by big business to be endlessly exploited in its own interests: "the smart city approach to solving urbanisation is not a stand-alone concept, being backed by corporations with substantial financial resources. The two main leaders are Cisco and Siemens closely followed by IBM, Hitachi, Microsoft, GE, Schneider Electric and Bosch" [73] (p. 7). To put this in perspective, Microsoft alone has revenue of US\$ 100 billion. Two brothers Charles and David Koch are together worth \$US 120 billion, whose philosophy is summed up by saying "Our movement must destroy the prevalent statist paradigm" [74] (online).

The causes of this global problem are clear. Nature has its own laws. However, the neocorporate state has adopted a mechanistic concept of nature which only recognizes its instrumental value within the market system. This allows corporations free reign to fly the flag of patriotism and benevolence while withholding tax revenues that in many cases could take entire nations out of debt and individuals out of extreme poverty. The terms green and sustainable now legitimize the very institutions that have bankrupted, polluted and exhausted nature-banks, finance, property and insurance companies and national and transnational corporations. Unfortunately, nature does not yield to the market without problems and an unsustainable planet is now the result. Attempts to solve climate change at Kyoto, Cancun, Brussels, Bali, Copenhagen and Paris have all failed disastrously, remaining alive only in rhetoric. Meanwhile, the combined environmental damage of the 3000 largest global companies has been conservatively estimated at \$USD 2.2 trillion [75]. This sum equals one third of their profits, which if paid as fines could bankrupt the global financial system. Even this is trivial to American debt (personal, institutional and national)—around \$US 50 trillion, a sum that can never be repaid by the world's largest debtor nation. So, the real answers to the problem of sustainability lie in the transformation of capitalism, for no "environmental" solutions begin to attack the fundamental issue of environmental justice- the moral economy that lies at the heart of a sustainable planet. Contrary to natural capitalism sustainability does not imply social equality and largely depends on technology for results, and it is to this issue we now turn. 


\subsection{Corporate Power, the Smart City and Sustainable Development}

Not only is the smart city weltanschuung linked to natural capitalism, it is also inseparable from a biased interpretation of sustainability. In terms of corporate power this has always meant the survival of the corporation at all costs-no business ever plans to go extinct, to make losses in the future, to sacrifice market share for a moral principle or a nebulous climate change. Emanating from the same philosophy, the fourth industrial revolution is likely to establish a system of exploitation and social control based upon a hypertech industrial revolution whose outcomes are necessarily undefined yet potentially socially coercive and manipulative [76]. History demonstrates that all societies are class divided in some form and that the objectives of social control via commodification possess universal properties. So instead of looking for the atomic structure of "smartness," it seems more profitable to expose the critical relationships between natural capitalism and sustainability before even thinking about smart cities. Our thesis here is simple-due to the ambiguous interpretations of sustainability (each enterprise interpreting the word according to its own objectives)-there can be no significant explanation of the term outside a theory of capital accumulation linked to urban development. "Sustainability" has been resolutely co-opted by big capital, where the semantic implications of the term accommodate business interests over the social, as in "sustainable leadership", "leveraging sustainability" in business, using "sustainability consultancy" and "sustainable accounting" and relying on "sustainable banking systems" [77]. We now have green/sustainable formula one race cars, oil companies, banks, corporations, NGOs, etc. Even the minimalist attempt at global carbon trading has already been corrupted by big capital, and carbon piracy is now in full swing in the Peruvian Amazon [78].

So, in the deepening of capitalist social relations, the term sustainability assumes chameleon like properties. It obscures the fact that poverty and scarcity are socially produced phenomena, emanating from an unequal distribution of wealth and ideological control over political systems. Nobody volunteers to be poor. So, neo-Darwinism also rules at the corporate level. No corporation will voluntarily sacrifice market share to sustainable practices. No nation will willingly sacrifice gross development product for the greater good. Furthermore, no politician will sacrifice votes to their moral conscience. As Jean-Claude Juncker of the European Union said "We all know what to do, we just don't know how to get re-elected after we've done it" [79] (online). Oxfam has broadcast that the existence of such extreme inequality in Indonesia could destabilize the country's economy [80]. For example, only the interest on the wealth of two sibling billionaires (the Hartono Brothers) who control \$US 25 billion, could raise one hundred million of their poorest countrymen out of extreme poverty ( $40 \%$ of the population). This figure is based upon the World Bank's "moderate" poverty line of \$ 3.10-a-day (IDR 1.500,000 per month) [81]. This sum has to be compared to Walter Piketty's observation that if planetary GDP was divided by the total population, each person could be allocated the sum of 750 Euros per month (IDR 12,000,000). The moderately poor in Indonesia receive $12.5 \%$ of that amount.

So not only is the term "sustainable" semantically void, it is now positively subversive, being used to enhance the strategies of the world's largest polluters and their ongoing destruction of nature. Populations in the wealthy countries of the north now support an ideologically biased sustainability that provides subliminal cover for corporate rape and pillage to continue. This undermines their own best interests, extends the destruction of nature, increases levels of pollution and imposes yet another layer of imperialism on the developing world of the global south. Paradoxically it is precisely these properties that permit capital duplicitous politics, guaranteeing support on the one hand (via hand-outs) yet denying it on the other (through tax fraud). Transnational corporations, banks, insurance companies etc. present as benevolent institutions, helping individuals and communities to grow and prosper while flaunting every tax loophole yet invented, thus undermining the very communities they purport to assist. In 2018, 60 of the largest American companies paid no taxes on US 79 billion in income [82]. Amazon and Netflix together should have paid $\$ 16.4$ billion in federal income taxes. Instead, they received a net tax rebate of $\$ 4.3$ billion. These multinationals advertise 
themselves to the public as philanthropists, whose only concern is with families, communities and the health of children. They benevolently advertise that we are all together in this battle against climate change, pollution, and the destruction of natural resources as they transfer billions into shareholders pockets at the cost of global warming and threatening life on earth. It is precisely this mentality and ideology that infuses the smart city enterprise.

Clearly the term sustainable has been totally absorbed into the ideological structure of capitalism and its very use supports the false consciousness of the majority. It has become so corrupted not only to be meaningless but also to actually obscure and undermine the real social issues that must be dealt with surrounding exploitation, the undermining of democratic politics, the concentration of wealth and the absence of a moral economy to replace that of the market [83]. This is one of the two dominant platforms upon which smart cities are constructed. With its absorption by corporate interests, the term sustainable has been elevated to sublime uselessness. It has become a totally politicized ideology anointed with anodyne qualities.

As with our critique of the dominant technological paradigm that the smart city represents despite the huge advances that technology has offered, we would again wish to stress that significant and extensive work is being carried out where the term sustainability has not been completely politicized. There is no doubt that a moral conscience prevails in the work of a myriad committed individuals and research centers. We do not see these efforts as anything less than vital to the survival of the human race. However, what we have chosen to focus on here is the dark side of the sustainability equation. The good work being done demands to be recognized, but a sustained and enduring opposition must be pursued in order to continually expose the iniquity in unrestrained corporate intervention. We cannot afford to ignore that the vast power of multinational corporations has subdued the original moral principles inherent to a sustainable planet—-the pursuit of power over a shared human conscience.

\section{Conclusions}

There is no conclusion to the expanding smart city debate. However, in order to go beyond metaphors such as smart and describe the reality of the urban process, we have applied the principles of political economy. In the current academic environment, we consider that our chosen method, while not belonging to the rational-comprehensive scientific model, nonetheless makes a novel contribution to the smart city debate. We have done this by expanding the predominant research focus to the actual environment within which the smart city sits. In other words, it is situated within the historical, economic and political environment that we all recognize as urban life. It does this by extracting the smart city from the social vacuum that we maintain it currently occupies, and by so doing, seek to extend debate into the realm of the social rather than the technical. Without considering its relationship to genuine sustainable development and a perfidious natural capitalism, the smart city begins to appear as yet another branding exercise to manufacture a market for digital product, to perpetuate corporate power and to increase social control through technology. It is also clear to us that there are several dimensions to the problems outlined above that are difficult to address within the constraints of this paper. These would include the entire range of strategies, policies, and models. That could conceivably mitigate the effects we have outlined above, and further research is intended to explore these dimensions of the problem in greater depth. As we have indicated, the actual crisis is the crisis of the capitalist global economy not merely of its institutions and monopolistic practices.

At the time of writing we are still in the midst of a pandemic that has killed over a million people and where there seems to be no end to the crisis. While we accept that we could suggest many changes to economic and political systems to obviate the problems indicated above, there is no doubt that the pandemic is already suggesting an extensive matrix of political and social change. The dominant practice appears to be a switch within conservative political systems from Friedmanite economics to those of Maynard Keynes. The inherent redistribution of wealth suggests how a more globally democratic system could be implemented. The core values that seem to emerge involve a vastly more equitable redistribution of resources (for example, a universal basic income, increased social welfare 
and public health benefits and higher taxation for the rich). It is also clear that the whole principle of dual technology should be further explored.

So, the real answers to the problem of sustainability lie in the transformation of capitalism not in smarter cities. Few sustainable solutions begin to attack the fundamental issue of environmental justice-a moral economy that lies at the heart of a sustainable planet and we only have to look to Australia to see the vast economic support now given to the general population that previously went to sustain private sector profits. Forget the idea expressed in Natural Capitalism that a wholly acceptable and sustainable capitalism will evolve, while hiding the fact that its structure will remain unaltered. We propose that a major flaw exists both in terms of social development and technical processes, namely that a new moral conscience must be adopted by scholars and practitioners alike and once again that we can see indications of this in select government responses to the COVID-19 pandemic across the globe. This would demand that the smart city concept and its implementation in all forms should evaluate the social consequences of new technologies in parallel with the binary logic of computing. Simply stated, lifestyle, environment, community and humanity should be foremost in our work and all technologies, smart or otherwise, tied to improving these objectives. Let us live with a true respect for nature based in moral principles where environmental justice prevails.

Author Contributions: The conceptualization and the methodology were undertaken by G.A.M.S. and A.C. Formal analysis was undertaken by G.A.M.S. Original draft preparation by both authors, with review and editing by G.A.M.S. There is no visualization in the article, nor was any supervision or administration required. There was mutual agreement that G.A.M.S. should be the corresponding and lead author. Funding acquisition was provided by G.A.M.S. All authors have read and agreed to the published version of the manuscript.

Funding: This research was funded by UDAYANA UNIVERSITY-BALI, Indonesia, grant number B/1588-55/UN14.4.A/PT.01.03/2020.

Conflicts of Interest: The authors declare no conflict of interest.

\section{References}

1. Greenfield, A. Radical Technologies: The Design of Everyday Life, 1st ed.; Verso: London, UK, 2017.

2. Wittgenstein, L. Tractatus Logico-Philosophicus, 1st ed.; Harcourt, Brace \& Company Inc.: New York, NY, USA, 1922.

3. Schwab, K. The Fourth Industrial Revolution. Available online: https://www.weforum.org/about/the-fourthindustrial-revolution-by-klaus-schwab (accessed on 15 June 2019).

4. Petre, P. Knowledge Horizons. Economics 2016, 8, 57-62.

5. Harvey, D. The Urban Process under Capitalism: A Framework for Analysis. In Urbanisation and Urban Planning in Capitalist Society, 1st ed.; Dear, M., Scott, A.J., Eds.; Methuan \& Co. Ltd.: London, UK, 1981; pp. 91-122.

6. Dunleavy, P. The Politics of Mass Housing in Britain: 1945-75, 1st ed.; Clarendon Press: Oxford, UK, 1983.

7. Park, Y.J. Development of a Revenue Model for Buyers in Co-Creation Environment. Int. J. Adv. Sci. Eng. Inf. Technol. 2020, 10, 578-584. [CrossRef]

8. Lefebvre, H. The Production of Space, 1st ed.; Wiley-Blackwell: Oxford, UK, 1992.

9. Stilwell, F. From Economics to Political Economy: Contradictions, Challenge, and Change. Am. J. Econ. Soc. 2019, 78, 35-62. [CrossRef]

10. Cardullo, P.; Kitchin, R. Smart Urbanism and Smart Citizenship: The Neoliberal Logic of Citizen-Focused Smart Cities in Europe. Environ. Plan. C Politic Space 2019, 37, 813-830. [CrossRef]

11. Sung-Yueh, P.; Maalsen, S. Civic Infrastructure and the Appropriation of the Corporate Smart City. Ann. Am. Assoc. Geogr. 2020, 110, 507-515.

12. Gandy, O.H.; Nemorin, S. Toward a Political Economy of Nudge: Smart City Variations. Information. Commun. Soc. 2019, 22, 2112-2126. [CrossRef]

13. Cook, M. Inside Smart Cities: Place, Politics and Urban Environment. Local Environ. 2019, 24, 554-555. [CrossRef]

14. Castells, M. The Urban. Question: A Marxist Approach, 1st ed.; The MIT Press: Cambridge, MA, USA, 1977.

15. Sayer, A. A critique of Urban Modelling. Prog. Plan. J. 1976, 6, 187-254. [CrossRef] 
16. Albino, V.; Berardi, U.; Dangelico, R. Smart Cities: Definitions, Dimensions, Performance, and Initiatives. Available online: https://www.tandfonline.com/doi/pdf/10.1080/10630732.2014.94209 (accessed on 5 July 2019).

17. Chan, B. The Smart City Ecosystem Framework-A Model for Planning Smart Cities 2018. Available online: https://www.Iotforall.Com/Smart-City-Ecosystem-Framework-Model-For-Planning-Smart-Cities/ (accessed on 30 June 2019).

18. Sterling, B. There is No Such Thing as a Smart City. 2018. Available online: https://www.theatlantic.com/ technology/archive/2018/02/stupid-cities/553052/ (accessed on 30 June 2019).

19. Samih, H. Smart Cities and the Internet of Things. J. Inf. Technol. Case Appl. Res. 2019, 21, 3-12. [CrossRef]

20. Trindade, P.E.; Trindade, E.P.; Hinnig, M.P.F.; Da Costa, E.M.; Marques, J.S.; Bastos, R.C.; Yigitcanlar, T. Sustainable Development of Smart Cities: A Systematic Review of the Literature. J. Open Innov. Technol. Mark. Complex. 2017, 3, 1-14. [CrossRef]

21. Liu, C.; Ren, L.; Wu, L.; Guo, M. Measuring the Smart Growth Pattern for Medium-Sized Cities. J. Urban. Plan. Dev. 2020, 146. [CrossRef]

22. Mancebo, F. Smart City Strategies: Time to Involve People. Comparing Amsterdam, Barcelona and Paris. J. Urban. 2020, 13, 133-152. [CrossRef]

23. Karppi, I.; Vakkuri, J. Becoming Smart? Pursuit of Sustainability in Urban Policy Design. Public Manag. Rev. 2020, 22, 746-766. [CrossRef]

24. Harvey, D. Social Justice, Postmodernism and the City. In Designing Cities-Critical Readings in Urban Design, 1st ed.; Cuthbert, A., Ed.; Blackwell: Oxford, UK, 2003; pp. 101-115.

25. Bottomore, T. A Dictionary of Marxist Thought, 1st ed.; Blackwell: Oxford, UK, 1988.

26. Florida, R. The Rise of the Creative Class, 1st ed.; Basic Books: New York, NY, USA, 2004.

27. Florida, R. The Flight of the Creative Class, 2nd ed.; Harper Business: New York, NY, USA, 2007.

28. Bakunin, M. Bakunin on Anarchism, 1st ed.; Knopf: New York, NY, USA, 1971.

29. Djilas, M. The New Class: Analysis of the Communist System, 1st ed.; Thames and Hudson: London, UK, 1982.

30. Gouldner, A. The Future of Intellectuals and the Rise of the New Class, 1st ed.; Seabury Press: New York, NY, USA, 1979.

31. Piketty, W. Capital-in the Twenty First Century, 1st ed.; Harvard University Press: Boston, MA, USA, 2010.

32. Myers, J. Trump vs. Koch Is a Custody Battle over Congress. Available online: https://www.newyorker.com/ news/news-desk/trump-vs-koch-is-a-custody-battle-over-congress (accessed on 4 July 2019).

33. Billionaire. Available online: https://en.wikipedia.org/wiki/Billionaire (accessed on 17 June 2019).

34. Singh, S. Smart Cities-A \$1.5 Trillion Market Opportunity. Available online: https://www.forbes.com/sites/ sarwantsingh/2014/06/19/smart-cities-a-1-5-trillion-market-opportunity/ (accessed on 17 June 2019).

35. Huxley, A. Brave New World, 1st ed.; Chatto \& Windus: London, UK, 2006.

36. Orwell, G. Nineteen Eighty-Four; Secker \& Warburg: London, UK, 1984.

37. Pool, S. The Truth about Smart Cities: In the End, They will Destroy Democracy. Available online: https://www. theguardian.com/cities/2014/dec/17/truth-smart-city-destroy-democracy-urban-thinkers-buzzphrase (accessed on 19 June 2019).

38. Saunders, P. Social Theory and the Urban. Question, 1st ed.; Hutchinson: London, UK, 1986.

39. Tomitsch, M. Making Cities Smarter: Designing Interactive Urban Applications, 1st ed.; Jovis: Berlin, Germany, 2018.

40. Stimmel, C. Building Smart Cities: Analytics, ICT, and Design Thinking, 1st ed.; CRC Press, Taylor \& Francis Group: Boca Raton, FL, USA, 2016.

41. Townsend, A. Smart Cities Big Data, Civic Hackers, and the Quest for a New Utopia, 1st ed.; W. W. Norton \& Company: New York, NY, USA, 2013.

42. Boorsama, B. A New Digital Deal: Beyond Smart Cities. How to Best Leverage Digitalization for the Benefit of Our Communities, 1st ed.; Boekscout BV: GC Soest, the Netherlands, 2017.

43. Harvey, D. The New Imperialism, 1st ed.; Oxford University Press: Oxford, UK, 2003.

44. Suartika, G.A.M.; Cuthbert, A.R.; Putra, G.M.; Saputra, K.E. Public Domain and Cultural Legacy: The Governance of a Sacred and Vernacular Cultural Landscape in Bali. ISVS e-J. 2020, 7, 1-22.

45. Suartika, G.A.M.; Cuthbert, A.R. Sleight of Hand: The Expropriation of Balinese Culture. J. Space Cult. 2020, 1-22. [CrossRef] 
46. Suartika, G.A.M.; Cuthbert, A.R.; Zerby, J. Doors of Perception to Space-Time-Meaning: Ideology, Religion, and Aesthetics in Balinese Development. J. Space Cult. 2018, 21, 340-357. [CrossRef]

47. Cuthbert, A.R. Urban Decay and Regeneration: Context and issues. J. Urban. Des. 2017, 22, 140-143. [CrossRef]

48. Wiig, A. Secure the City, Revitalize the Zone: Smart Urbanization in Camden, New Jersey. Environ. Plan. C Politics Space 2018, 36, 403-422. [CrossRef]

49. Taweesaengsakulthai, S.; Laochankham, S.; Kamnuansilpa, P.; Wongthanavasu, S. Thailand Smart Cities: What is the Path to Success? Asian Politics Policy 2019, 11, 144-156. [CrossRef]

50. Wachsmith, D.; Angelo, H. Green and Gray: New Ideologies of Nature in Urban Sustainability Policy. Ann. Am. Assoc. Geogr. 2018, 108, 1038-1056. [CrossRef]

51. Hatuka, T.; Rosen-Zvi, I.; Birnhack, M.; Toch, E.; Zur, H. The Political Premises of Contemporary Urban Concepts: The Global City, the Sustainable City, the Resilient City, the Creative City, and the Smart City. Plan. Theory Pract. 2018, 19, 160-179. [CrossRef]

52. The Guardian, the Mexican Town that Refused to Become a Smart City. Available online: https://www. theguardian.com/cities/2018/oct/16/the-mexican-town-that-refused-to-become-a-smart-city (accessed on 23 June 2019).

53. Economic Development Board Mauritius. Smart City Scheme. Available online: http://www.edbmauritius. org/schemes/smart-city-scheme/ (accessed on 23 June 2019).

54. Sahadut, M.; Bundhoo, M.; Catherine, P. Development of Smart Cities in Mauritius. Requirements, Challenges and Opportunities. In Proceedings of the Second International Conference on Data Mining, Internet Computing, and Big Data, Reduit, Mauritius, 29 June-1 July 2015; pp. 69-83.

55. Hall, P. Cities of Tomorrow: An Intellectual History of Urban Planning and Design in the Twentieth Century, 1st ed.; Blackwell Publishers: Oxford, UK, 1996.

56. Scott, A.; Roweis, S. Urban Planning in Theory and Practice-a Reappraisal. Environ. Plan. A J. 1977, 9 , 1097-1119. [CrossRef]

57. King, R. Brunelleschi's Dome, 1st ed.; Bloomsbury: New York, NY, USA, 2013.

58. Hall, P. Cities in Civilisation, 1st ed.; Pantheon: New York, NY, USA, 1998.

59. Lang, J. Urban Design: A Typology of Procedures and Products, 1st ed.; Routledge: London, UK, 2017.

60. Williams, R. Why Cities Look the Way They Do, 1st ed.; Polity Press: Oxford, UK, 2019.

61. Smith, P.D. Talk of the Town. Guard. Wkly. 2019, 201, 59.

62. Hawken, P.; Lovins, A.; Lovins, L. Natural Capitalism: Creating the Next Industrial Revolution, 1st ed.; Little, Brown and Company: New York, NY, USA, 1999.

63. Hargroves, K.C.; Smith, M. The Natural Advantage of Nations; Earthscan: London, UK, 2005.

64. Herring, H.; MacKerron, G.; Boehmer-Christiansen, S. Natural Capitalism: The New Utopia, the Environment and Competition in Electricity in the USA and the UK, Cleaner Air and Better Transport. Energy Environ. J. 2000, 11, 597-601. [CrossRef]

65. Kendall, B.E. Personae and Natural Capitalism: Negotiating Politics and Constituencies in a Rhetoric of Sustainability. Environ. Commun. J. 2008, 2, 59-77. [CrossRef]

66. Trainer, F.E. Natural Capitalism Cannot Overcome Resource Limits. Available online: http://www. mnforsustain.org/trainer_fe_simon_lovins_critique.htm (accessed on 30 April 2019).

67. Slesser, M. Misleading Us or Deluding Themselves? Feasta Review Number 1. Available online: https: //www.feasta.org/documents/feastareview/slesser.htm (accessed on 4 July 2019).

68. Monbiot, G. Put a Price on Nature? We Must Stop this Neoliberal Road to Ruin. Available online: https://www.theguardian.com/environment/georgemonbiot/2014/jul/24/price-nature-neoliberalcapital-road-ruin (accessed on 4 July 2019).

69. Martini, J. Is there a Natural Capital? A Critique of the Ecological Economics Approach. Int. J. Earth Environ. Sci. 2016, 1, IJEES-123. [CrossRef]

70. Monbiot, G. The Pricing of Everything. Available online: https://www.monbiot.com/2014/07/24/the-pricingof-everything/ (accessed on 4 July 2019).

71. Younge, G. Who's in Control-Nation States or Global Corporations. Available online: https://www. theguardian.com/commentisfree/2014/jun/02/control-nation-states-corporations-autonomy-neoliberalism (accessed on 4 July 2019). 
72. Friedman, M. Milton Fiedman Quotes. Available online: https://www.goodreads.com/author/quotes/5001 (accessed on 3 April 2019).

73. Allam, Z.; Newman, P. Redefining the Smart City: Culture, Metabolism and Governance. Smart Cities J. 2018, 1, 4-25. [CrossRef]

74. Myers, J. How do the World's Biggest Companies Compare to the Biggest Economies? Available online: https://www.weforum.org/agenda/2016/10/corporations-not-countries-dominate-the-list-of-theworld-s-biggest-economic-entities/ (accessed on 20 July 2019).

75. Jowit, J. World's Top Firms Cause \$2.2 Ton of Environmental Damage, Report Estimates. Available online: https://www.theguardian.com/environment/2010/feb/18/worlds-top-firms-environmental-damage (accessed on 25 May 2019).

76. Lyon, D. Theorizing Surveillance, 1st ed.; Taylor and Francis: London, UK, 2006.

77. Cuthbert, A.R. Sustainable Theory: Sustainable Form-The Future of Urban Design. In Sustainable Urbanism and Beyond: Rethinking Cities for the Future, 1st ed.; Haas, T., Ed.; Rizzoli: New York, NY, USA, 2010; pp. 9-17.

78. Vidal, J. Peruvian Amazon Could Become the Global Centre of Carbon Piracy. Available online: https://www. theguardian.com/environment/2011/nov/30/peruvian-amazon-carbon-piracy (accessed on 30 June 2019).

79. BBC, Profile: EU's Jean Claude Juncker. Available online: https://www.bbc.com/news/world-europe-27679170 (accessed on 30 July 2019).

80. Sayer, R.A. Interrogating the Legitimacy of Extreme Wealth: A Moral Economic Perspective. In Handbook on Wealth and the Super-Rich, 1st ed.; Hay, I., Beaverstock, J.V., Eds.; Edward Elgar: London, UK, 2016; pp. 94-112.

81. Neate, R. Indonesia's Four Richest Men Worth as Much as Poorest 100 Million. Available online: https://www.theguardian.com/world/2017/feb/23/indonesias--four-richest-men-own-same-ascountrys-poorest-100-million (accessed on 5 July 2019).

82. Cerullo, M. 60 of America's Biggest Companies Paid No Federal Income Tax in 2018. Available online: https://www.cbsnews.com/news/2018-taxes-some-of-americas-biggest-companies-paid-little-tono-federal-income-tax-last-year/ (accessed on 5 July 2019).

83. Sayer, A. Approaching Moral Economy. In The Moralization of the Market, 1st ed.; Sther, N., Henning, C., Weiler, B., Eds.; Transaction Publishers: Brunswick, GA, USA, 2006; pp. 77-97.

Publisher's Note: MDPI stays neutral with regard to jurisdictional claims in published maps and institutional affiliations.

(C) 2020 by the authors. Licensee MDPI, Basel, Switzerland. This article is an open access article distributed under the terms and conditions of the Creative Commons Attribution (CC BY) license (http://creativecommons.org/licenses/by/4.0/). 